\title{
Agromyces soli sp. nov., isolated from farm soil
}

\author{
Correspondence \\ Myungjin Lee \\ mgeneli@dreamwiz.com
}

\author{
Myungjin Lee, ${ }^{1}$ Leonid N. Ten, ${ }^{2}$ Sung-Geun Woo ${ }^{1,3}$ and Joonhong Park ${ }^{3}$ \\ ${ }^{1}$ Research and Development Division, H-Plus Eco Ltd, BVC 301, KRIBB, Eoeun-dong, \\ Yuseong-gu, Daejeon, 305-333, Republic of Korea \\ ${ }^{2}$ Bioenergy Research Center, Korea Institute of Energy Research, 102, Gajeong-ro, Yuseong-gu, \\ Daejeon, 305-343, Republic of Korea \\ ${ }^{3}$ School of Civil and Environmental Engineering, Yonsei University, Seoul, 120-749, \\ Republic of Korea
}

The genus Agromyces, with Agromyces ramosus as the type species, was established by Gledhill \& Casida (1969) to accommodate microaerophilic to aerobic, filamentous, branching, fragmenting, catalase- and oxidase-negative actinomycetes isolated from soil. Zgurskaya et al. (1992) emended the description of the genus and added two species, each with two subspecies, Agromyces cerinus subsp. cerinus, A. cerinus subsp. nitratus, Agromyces fucosus subsp. fucosus and $A$. fucosus subsp. hippuratus, which are characterized by rapid growth on simple media and show positive catalase and oxidase reactions. At the time of writing, the genus Agromyces comprises 22 recognized species: A. ramosus (Gledhill \& Casida, 1969), A. cerinus (Zgurskaya et al., 1992), A. mediolanus (Suzuki et al., 1996), A. luteolus, A. rhizospherae and A. bracchium

The GenBank/EMBL/DDBJ accession number for the 16S rRNA gene sequence of strain MJ21 $1^{\top}$ is GQ241325.

One supplementary table and two supplementary figures are available with the online version of this paper.
(Takeuchi \& Hatano, 2001), A. albus (Dorofeeva et al., 2003), A. aurantiacus (Li et al., 2003), A. fucosus and A. hippuratus (Zgurskaya et al., 1992; Ortiz-Martinez et al., 2004), A. ulmi (Rivas et al., 2004), A. neolithicus and A. salentinus (Jurado et al., 2005a), A. humatus, A. italicus and A. lapidis (Jurado et al., 2005b), A. subbeticus (Jurado et al., 2005c), A. allii (Jung et al., 2007), A. terreus (Yoon et al., 2008), A. atrinae (Park et al., 2010), A. bauzanensis (Zhang et al., 2010) and A. tropicus (Thawai et al., 2011). Most of the above-mentioned species were isolated from soil and the rhizosphere of plants. Here we describe a Grampositive, rod-shaped bacterial strain, designated $\mathrm{MJ} 21^{\mathrm{T}}$, which was isolated from a soil sample. Phenotypic, chemotaxonomic and phylogenetic analyses established that this isolate was affiliated with the genus Agromyces. The data obtained suggest that the isolate represents a novel species of the genus.

Strain MJ21 ${ }^{\mathrm{T}}$ was isolated from a farm soil sample collected near Daejeon, South Korea. The sample was suspended and 
spread on R2A agar (Difco) plates after being serially diluted with $50 \mathrm{mM}$ phosphate buffer ( $\mathrm{pH}$ 7.0). The plates were incubated at $25{ }^{\circ} \mathrm{C}$ for 2 weeks. Single colonies on the plates were purified by transferring them onto fresh plates and incubating them again under the same conditions. The isolate was routinely cultured on R2A agar at $25{ }^{\circ} \mathrm{C}$ and maintained as a glycerol suspension $(20 \%, \mathrm{w} / \mathrm{v})$ at $-70{ }^{\circ}$ C. A. ulmi KACC $20592^{\mathrm{T}}$, A. aurantiacus KCTC $9967^{\mathrm{T}}$, A. mediolanus JCM $3346^{\mathrm{T}}$, A. mediolanus JCM 1376, A. mediolanus JCM 9632, A. mediolanus JCM 9633 and A. mediolanus JCM 9631 were used as reference strains for DNA-DNA hybridization and other experiments.

The Gram reaction was determined by using a Gram-stain kit (Difco) according to the manufacturer's instructions. Additionally, the Gram reaction was tested by using the non-staining method, as described by Buck (1982). Cell morphology was observed under a Nikon light microscope at $\times 1000$ magnification with cells grown at $25{ }^{\circ} \mathrm{C}$ on nutrient agar. Motility was tested by using the hangingdrop technique. Additionally, motility was studied on Luria-Bertani (LB) swarming agar $(0.3 \%$, w/v). The oxidase reaction was tested on filter paper moistened with a $1 \%(\mathrm{w} / \mathrm{v})$ aqueous solution of $N, N, N^{\prime}, N^{\prime}$-tetramethyl-pphenylenediamine, and catalase activity was demonstrated by using $3 \%(\mathrm{v} / \mathrm{v})$ hydrogen peroxide as outlined by Cappuccino \& Sherman (2002). The test for anaerobic growth in LB medium was performed in $10 \mathrm{ml}$ anaerobic jars with rubber septa (Sigma) that were evacuated with hydrogen gas and then incubated at $25{ }^{\circ} \mathrm{C}$ for 7 days. Microaerophilic growth was tested in semi-liquid LB medium containing $0.4 \%$ agar. Assimilation of single carbon sources, enzyme activities, acid production from substrates and other physiological characteristics were determined with the API ID 32 GN (AUX medium, $48 \mathrm{~h}$, $\left.28{ }^{\circ} \mathrm{C}\right)$, API ZYM $\left(0.85 \% \mathrm{NaCl}\right.$ medium, $\left.4 \mathrm{~h}, 28{ }^{\circ} \mathrm{C}\right)$, API 20NE (AUX medium, $48 \mathrm{~h}, 28{ }^{\circ} \mathrm{C}$ ) and API $50 \mathrm{CH}$ (API 50 $\mathrm{CHB}$ medium, $48 \mathrm{~h}, 28{ }^{\circ} \mathrm{C}$ ) galleries according to the manufacturer's instructions (bioMérieux). Cells for inoculation of the strips were grown for 2 days at $28{ }^{\circ} \mathrm{C}$ in $\mathrm{LB}$ broth. Hydrolysis of casein was examined on nutrient agar supplemented with $1.5 \%$ dry skimmed milk (Tindall et al., 2007). Chitinase activity was tested by using R2A agar medium supplemented with colloidal chitin $\left(4 \mathrm{~g} \mathrm{l}^{-1}\right)$ (Hsu \& Lockwood, 1975). Hydrolysis of starch was tested on nutrient agar plates supplemented with soluble starch $\left(10 \mathrm{~g} \mathrm{l}^{-1}\right)$. Starch hydrolysis was detected by flooding the plates with iodine solution (Tindall et al., 2007). Tests for degradation of DNA [DNase agar (Scharlau), with DNase activity detected by flooding plates with $1 \mathrm{M} \mathrm{HCl}$ ] were performed according to Collins \& Lyne (1984). Hydrolysis of xylan and HE-cellulose was determined with a nutrient agar medium supplemented with a mixture of chromogenic substrates (xylan-red and HE-cellulose-blue), as described previously (Ten et al., 2004). Growth at 4, 10, $15,20,25,30,37$ and $42{ }^{\circ} \mathrm{C}$ was assessed on R2A agar, nutrient agar, LB agar, trypticase soy agar (TSA; Difco) and MacConkey agar after 5 days of incubation. Growth at
pH 5.0-10.0 (at intervals of $0.5 \mathrm{pH}$ units) was assessed after incubation for 5 days at $25{ }^{\circ} \mathrm{C}$. The effect of $\mathrm{pH}$ on growth was determined in $\mathrm{R} 2 \mathrm{~A}$ broth by using three different buffers (final concentration, $50 \mathrm{mM}$ ): sodium acetate buffer (for $\mathrm{pH}$ 5.0-5.5), potassium phosphate buffer (for $\mathrm{pH}$ 6.0-8.0) and $\mathrm{Na}_{2} \mathrm{CO}_{3} / \mathrm{NaHCO}_{3}$ buffer (for $\mathrm{pH}$ 8.5-10.0).

For phylogenetic analysis, genomic DNA was extracted by using a commercial genomic DNA extraction kit (Solgent) and PCR-mediated amplification of the 16S rRNA gene and sequencing of the purified PCR product were carried out according to Kim et al. (2005). Full sequences of the $16 \mathrm{~S}$ rRNA gene were compiled by using SeqMan software (DNASTAR). The 16S rRNA gene sequences of related taxa were obtained from the GenBank database. Multiple alignments were performed by using the program CLUSTAL X (Thompson et al., 1997). Gaps were edited in the program BioEdit (Hall, 1999). Evolutionary distances were calculated by using the Kimura two-parameter model (Kimura, 1983). A phylogenetic tree was reconstructed by using the neighbour-joining (Saitou \& Nei, 1987) and maximum-parsimony (Fitch, 1971) methods within the program MEGA4 (Tamura et al., 2007) with bootstrap values based on 1000 replications (Felsenstein, 1985).

For measurement of the chromosomal DNA G+C content, genomic DNA was extracted and purified as described by Moore \& Dowhan (1995) and was degraded enzymically into nucleosides; the DNA G $+\mathrm{C}$ content was determined as described by Mesbah et al. (1989) by using reversed-phase HPLC. Isoprenoid quinones were extracted with chloroform/methanol $(2: 1, \mathrm{v} / \mathrm{v})$, evaporated under vacuum conditions and re-extracted in $\mathrm{n}$-hexane/water $(1: 1, \mathrm{v} / \mathrm{v})$. The crude quinone in $\mathrm{n}$-hexane was purified by using Sep-Pak Vac silica cartridges (Waters) and was then analysed by HPLC, as described by Hiraishi et al. (1996). Cellular fatty acids were analysed in cells grown on TSA for $24 \mathrm{~h}$ at $28{ }^{\circ} \mathrm{C}$. The cellular fatty acids were saponified, methylated and extracted according to the protocol of the Sherlock Microbial Identification System (MIDI). Fatty acid methyl esters were then analysed by GC (model 6890; Hewlett Packard) by using the Microbial Identification software package (Sasser, 1990). Polar lipids were extracted according to the procedure described by Minnikin et al. (1984) and were identified by two-dimensional TLC followed by spraying with appropriate detection reagents as described previously (Lee et al., 2008). Purified cell-wall preparations were obtained by using the method of Schleifer (1985). Amino acids and peptides in cell-wall hydrolysates were analysed by two-dimensional TLC on cellulose plates with the solvent systems described by Schleifer \& Kandler (1972). Sugar analysis of the purified cell wall was performed as described by Staneck \& Roberts (1974).

Cells of strain $\mathrm{MJ} 21^{\mathrm{T}}$ were Gram-positive, non-motile, straight or curved rods $(0.3-0.4 \mu \mathrm{m}$ wide and $0.8-1.2 \mu \mathrm{m}$ long). Cells exhibited aerobic or microaerophilic growth, 
but no growth was observed under anaerobic conditions. Colonies grown in the light on R2A agar plates for 2 days at $25^{\circ} \mathrm{C}$ were $0.5-1.8 \mathrm{~mm}$ in diameter, circular, shiny, of low convexity, transparent and pale yellow. Colonies grown in the dark were colourless, indicating that pigment production was induced by light. Strain $\mathrm{MJ} 21^{\mathrm{T}}$ grew at $10-30{ }^{\circ} \mathrm{C}$; the optimum temperature for growth was $25^{\circ} \mathrm{C}$. Growth also occurred on nutrient agar, TSA and LB agar but not on MacConkey agar. Pigmentation was observed on all agar media tested and its intensity was dependent slightly on growth temperature. Filamentous elongation and branching were not observed on any growth media. Strain $\mathrm{MJ} 21^{\mathrm{T}}$ did not exhibit a rod-coccus growth cycle. The isolate was positive for catalase but showed a negative oxidase reaction with $N, N, N^{\prime}, N^{\prime}$-tetramethyl-p-phenylenediamine. Other morphological, physiological and biochemical characteristics of strain $\mathrm{MJ} 21^{\mathrm{T}}$ are given in the species description below. Phenotypic and chemotaxonomic characteristics that differentiate strain $\mathrm{MJ} 21^{\mathrm{T}}$ from its closest phylogenetic relatives are listed in Table 1. In particular, in contrast to all reference strains the new isolate was positive for alkaline phosphatase and acid production from L-fucose and gluconate. Furthermore, strain $\mathrm{MJ} 21^{\mathrm{T}}$ differed from its phylogenetically closest neighbours, A. mediolanus JCM 1376, A. mediolanus JCM 9632 and A. mediolanus JCM 9633 in 29, 24 and 30, respectively, of 113 characteristics examined.

The almost-complete 16S rRNA gene sequences of strain $\mathrm{MJ} 21^{\mathrm{T}}$ and A. mediolanus JCM $3346^{\mathrm{T}}$ determined in this study comprised 1409 and $1372 \mathrm{bp}$, respectively. As expected, an unusual $43 \mathrm{nt}$ insertion in the 16S rRNA gene sequence of $A$. mediolanus DSM $20152^{\mathrm{T}}$ (GenBank accession number X77449) was not detected. The $16 \mathrm{~S}$ rRNA gene sequence of A. mediolanus JCM $3346^{\mathrm{T}}$ (GenBank accession number HM641754) obtained here was used for phylogenetic analysis. 16S rRNA gene sequence similarity calculations after neighbour-joining analysis indicated that among recognized members of the family Microbacteriaceae the closest relatives of strain MJ21 ${ }^{\mathrm{T}}$ were A. ulmi XIL01 ${ }^{\mathrm{T}}$ (97.8\%), A. aurantiacus YIM $21741^{\mathrm{T}}(97.1 \%)$ and $A$. mediolanus JCM $3346^{\mathrm{T}}$ (96.7\%). Higher levels of $16 \mathrm{~S}$ rRNA gene sequence similarity were found with other strains of $A$. mediolanus, namely $A$. mediolanus JCM 1376 (99.1\%), A. mediolanus JCM 9632 (99.1\%), A. mediolanus JCM $9633(98.9 \%)$ and A. mediolanus JCM 9631 (96.5\%). This relationship between strain MJ $21^{\mathrm{T}}$ and other members of the genus Agromyces was also evident in the phylogenetic trees (Fig. 1 and Supplementary Fig. S1, available in IJSEM Online). The generally accepted criteria for delineating bacterial species state that strains with $16 \mathrm{~S}$ rRNA gene sequence dissimilarity above $3 \%$ or strains with a DNA-DNA relatedness value of less than $70 \%$ (as measured by hybridization) are considered to belong to separate species (Wayne et al., 1987; Stackebrandt \& Goebel, 1994). In view of this definition, the above-mentioned data indicate that strain $\mathrm{MJ} 21^{\mathrm{T}}$ can be clearly separated from other members of the genus Agromyces with the exception of the strains given above. For further verification of the taxonomic position of strain $\mathrm{MJ} 21^{\mathrm{T}}$, DNA-DNA hybridization was performed with its phylogenetically closest relatives.

DNA-DNA hybridization was performed fluorometrically according to the method of Ezaki et al. (1989), by using photobiotin-labelled DNA probes (Sigma) and microdilution wells (Greiner), with five replications for each sample. The highest and lowest values obtained for each sample were excluded and the means of the remaining three values are quoted as DNA-DNA hybridization values. Strain MJ21 ${ }^{\mathrm{T}}$ showed less than $57 \%$ DNA-DNA relatedness with all assayed Agromyces strains (see Supplementary Table S1), indicating that it is not related to them at the species level (Wayne et al., 1987; Stackebrandt \& Goebel, 1994).

Strain $\mathrm{MJ} 21^{\mathrm{T}}$ contained large amounts of the branchedchain fatty acids anteiso- $\mathrm{C}_{15: 0}(46.9 \%$ of the total), anteiso- $\mathrm{C}_{17: 0}(23.7 \%)$ and iso- $\mathrm{C}_{16: 0}(18.1 \%)$, a smaller amount of iso- $\mathrm{C}_{15: 0}(7.4 \%)$, and minor amounts of iso$\mathrm{C}_{17: 0}(1.7 \%)$, iso- $\mathrm{C}_{14: 0}(1.1 \%)$ and $\mathrm{C}_{16: 0}(1.1 \%)$. This fatty acid profile was similar to those of recognized species of the genus Agromyces, producing anteiso- $\mathrm{C}_{15: 0}$, anteiso$\mathrm{C}_{17: 0}$ and iso- $\mathrm{C}_{16: 0}$ as predominant components on a variety of different media (Suzuki et al.,1996; Takeuchi \& Hatano, 2001; Li et al., 2003; Rivas et al., 2004; Yoon et al., 2008). The amino acids 2,4-diaminobutyric acid, glutamic acid, glycine and alanine were detected in total hydrolysates of the cell-wall preparation of strain $\mathrm{MJ} 21^{\mathrm{T}}$. This composition is consistent with peptidoglycan type $\mathrm{B} 2 \gamma$, which has been reported for most members of the genus Agromyces. Cell-wall sugars found in strain $\mathrm{MJ}^{2} 1^{\mathrm{T}}$ were rhamnose, galactose and xylose. Galactose and rhamnose have been reported for most species of the genus Agromyces (Takeuchi \& Hatano, 2001; Dorofeeva et al., 2003; Li et al., 2003; Jurado et al., 2005a), while xylose has been found only in a few Agromyces species (Zgurskaya et al., 1992). The major polar lipids detected in strain $\mathrm{MJ} 21^{\mathrm{T}}$ were diphosphatidylglycerol, phosphatidylglycerol, two unknown glycolipids and one unidentified phospholipid (see Supplementary Fig. S2). This result is in good agreement with other species of the genus Agromyces; in particular, all of them produced diphosphatidylglycerol and phosphatidylglycerol as diagnostic phospholipids (Suzuki et al., 1996; Li et al., 2003; Jurado et al., 2005a; Zhang et al., 2010). Strain MJ $21^{\mathrm{T}}$ contained MK-12 $(85.8 \%)$ as the major menaquinone, with minor amounts of MK-11 (8.9\%) and MK-10 (5.3\%). The DNA G+C content of strain $\mathrm{MJ} 21^{\mathrm{T}}$ was $73.4 \mathrm{~mol} \%$, which is slightly higher than values reported for recognized species of the genus Agromyces (65.3-72.8 mol\%) (Li et al., 2003; Jurado et al., 2005a). However, the value still lies within the range expected for members of the same genus and the DNA $\mathrm{G}+\mathrm{C}$ content range of the genus Agromyces should be extended taking this into account.

The phenotypic and phylogenetic data presented here indicate that strain MJ $21^{\mathrm{T}}$ belongs to the genus Agromyces. The phylogenetic distinctiveness of strain $\mathrm{MJ} 21^{\mathrm{T}}$, together 
Table 1. Differential phenotypic characteristics between strain $M J 21^{\top}$ and its phylogenetically closest relatives in the genus Agromyces

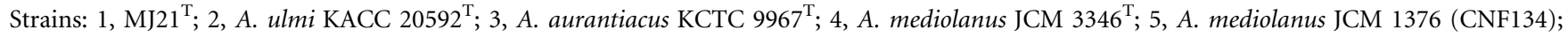
6, A. mediolanus JCM 9632 (CNF186); 7, A. mediolanus JCM 9633 (CNF208); 8, A. mediolanus JCM 9631 (CNF183). All data are from this study except where indicated. All strains are positive for aesculin hydrolysis but negative for Gram-stain reaction, $\mathrm{H}_{2} \mathrm{~S}$ and indole production. In API ID 32 GN, API 20NE (assimilation of carbon sources), API ZYM and API 50 CHB tests, all strains showed identical biochemical characteristics except those indicated here (see species description). W, Weakly positive reaction.

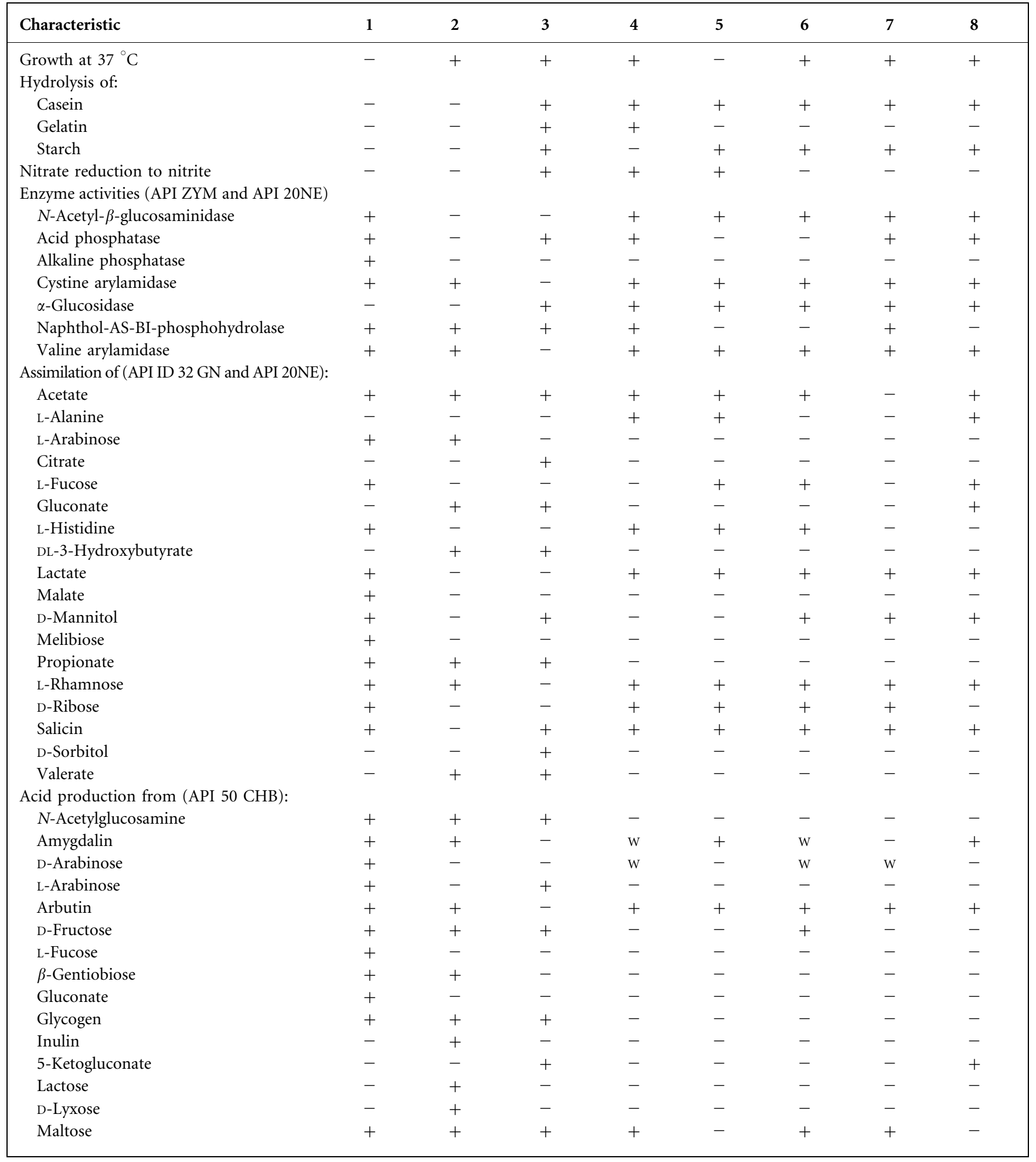


Table 1. cont.

\begin{tabular}{|c|c|c|c|c|c|c|c|c|}
\hline Characteristic & 1 & 2 & 3 & 4 & 5 & 6 & 7 & 8 \\
\hline D-Mannitol & + & - & + & - & - & - & - & - \\
\hline D-Mannose & + & + & + & + & - & + & - & - \\
\hline Melezitose & + & + & + & - & - & - & - & - \\
\hline Melibiose & - & + & + & - & - & - & - & - \\
\hline Methyl $\alpha$-D-glucopyranoside & + & + & + & - & - & - & - & - \\
\hline Methyl $\alpha$-D-mannopyranoside & + & + & - & - & - & - & - & - \\
\hline Raffinose & - & + & + & - & - & - & - & - \\
\hline D-Ribose & + & + & - & + & - & + & - & - \\
\hline Salicin & + & + & - & + & + & - & - & + \\
\hline L-Sorbose & - & + & - & - & - & - & - & - \\
\hline Starch & + & - & + & - & - & - & - & - \\
\hline Sucrose & + & + & + & + & - & + & - & - \\
\hline Trehalose & + & + & - & + & + & $\mathrm{W}$ & $\mathrm{w}$ & W \\
\hline Turanose & + & - & + & + & + & + & + & + \\
\hline Xylitol & - & + & - & - & - & - & - & - \\
\hline D-Xylose & + & + & - & - & - & - & - & - \\
\hline Cell-wall sugars* & $\begin{array}{c}\text { Rha, Gal, } \\
\text { Xyl }\end{array}$ & $\begin{array}{c}\text { Rha, Fuc, } \\
\text { Glu }{ }^{a_{\dagger}}\end{array}$ & $\begin{array}{l}\text { Rha, Gal, } \\
\text { Glu, Man }{ }^{b}\end{array}$ & $\begin{array}{l}\text { Rha, Man, } \\
\text { Gal }\end{array}$ & $\begin{array}{l}\text { Rha, Man, } \\
\text { Gal }\end{array}$ & $\begin{array}{c}\text { Rha, Man, } \\
\text { Gal }\end{array}$ & $\begin{array}{c}\text { Rha, Man, } \\
\text { Gal }\end{array}$ & $\begin{array}{c}\text { Rha, Man, } \\
\text { Glu }\end{array}$ \\
\hline \multirow[t]{2}{*}{ Menaquinone $(s) \S$} & MK-12 & MK-12 & MK- $12^{b}$ & MK-12 & MK-12 & MK-12 & MK-12 & MK-12 \\
\hline & $(-11,-10)$ & $(-11,-10)^{a}$ & & $(-11,-10)^{c}$ & $(-11,-10)^{c}$ & $(-11,-10)^{c}$ & $(-11,-10)^{c}$ & $=(-11,-10)^{c}$ \\
\hline DNA G $+C$ content $(\mathrm{mol} \%)$ & 73.4 & $72.0^{a}$ & $72.8^{b}$ & $72.3^{c}$ & $72.3^{c}$ & $72.3^{c}$ & $73.3^{c}$ & $72.8^{c}$ \\
\hline
\end{tabular}

${ }^{\star}$ Fru, fructose; Fuc, fucose; Gal, galactose; Glu, glucose; Man, mannose; Rha, rhamnose; Rib, ribose; Xyl, xylose.

$\dagger$ Data from: $a$, Rivas et al. (2004); b, Li et al. (2003); c, Suzuki et al. (1996).

$\$$ Menaquinones in parentheses are present as the next most common components.

with DNA-DNA hybridization data, confirmed that this strain represents a species that is distinct from recognized species of the genus Agromyces. Strain $\mathrm{MJ} 21^{\mathrm{T}}$ can be differentiated from phylogenetically related Agromyces strains based on several phenotypic characteristics (Table 1). Therefore, on the basis of the data presented, strain MJ $21^{\mathrm{T}}$ should be classified within the genus Agromyces as the type strain of a novel species, for which the name Agromyces soli sp. nov. is proposed.

\section{Description of Agromyces soli sp. nov.}

Agromyces soli (so'li. L. gen. n. soli of soil).

Cells are Gram-positive, aerobic to microaerophilic, straight or curved rods $(0.3-0.4 \mu \mathrm{m}$ wide and $0.8-1.2 \mu \mathrm{m}$ long). Growth occurs at $10-30{ }^{\circ} \mathrm{C}$ and at $\mathrm{pH}$ 5.0-9.0 (optimum $\mathrm{pH}$ 7.0-7.5). Nitrate is not reduced to nitrite. Hydrolyses DNA, but not casein, HE-cellulose, chitin, starch or xylan. In API ID $32 \mathrm{GN}$ and API 20NE tests, utilizes acetate,

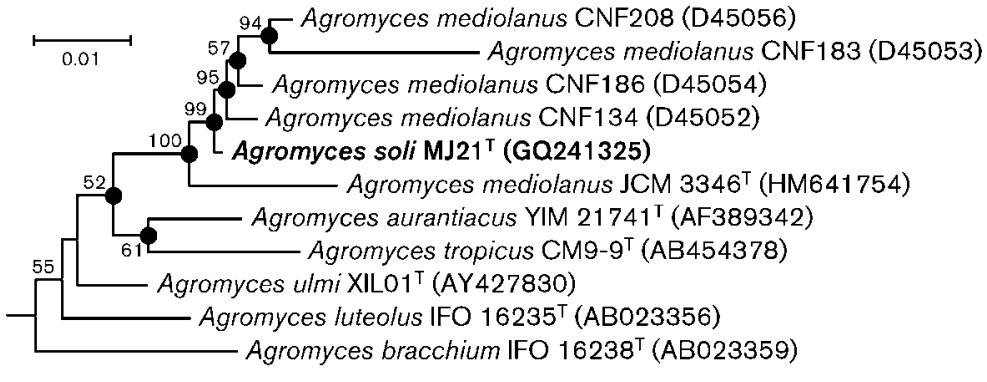

Fig. 1. Neighbour-joining tree, based on $16 \mathrm{~S}$ rRNA gene sequences, showing the phylogenetic position of strain $\mathrm{MJ} 21^{\top}$ among selected recognized members of the genus Agromyces. Bootstrap values (expressed as percentages of 1000 replications) of $>50 \%$ are shown at branch points. Arthrobacter globiformis DSM $20124^{\top}$ (GenBank accession number M23411) was used as an outgroup (not shown). Filled circles indicate that the corresponding nodes were also recovered in the tree generated with the maximum-parsimony algorithm. Bar, 0.01 substitutions per nucleotide position. An expanded version of this tree is available as Supplementary Fig. S1. 
$\mathrm{N}$-acetylglucosamine, L-arabinose, L-fucose, D-glucose, L-histidine, lactate, malate, maltose, D-mannitol, D-mannose, melibiose, propionate, L-rhamnose, D-ribose, salicin and sucrose for growth, but not adipate, L-alanine, caprate, citrate, gluconate, glycogen, 3-hydroxybenzoate, 4-hydroxybenzoate, DL-3-hydroxybutyrate, inositol, itaconate, 2-ketogluconate, 5-ketogluconate, malonate, phenylacetate, Lproline, L-serine, D-sorbitol, suberate or valerate. In API ZYM and API $20 \mathrm{NE}$ tests, positive for $N$-acetyl- $\beta$-glucosaminidase, acid phosphatase, alkaline phosphatase, cystine arylamidase, esterase $(\mathrm{C} 4)$, esterase lipase $(\mathrm{C} 8), \beta$-galactosidase, $\beta$-glucosidase, leucine arylamidase, naphthol-AS-BIphosphohydrolase, trypsin and valine arylamidase, but negative for arginine dihydrolase, $\alpha$-chymotrypsin, $\alpha$ fucosidase, $\alpha$-galactosidase, $\alpha$-glucosidase, $\beta$-glucuronidase, lipase (C14), $\alpha$-mannosidase and urease. In API $50 \mathrm{CHB}$ tests, acid is produced from $\mathrm{N}$-acetylglucosamine, aesculin, amygdalin, D-arabinose, L-arabinose, arbutin, cellobiose, Dfructose, L-fucose, D-galactose, $\beta$-gentiobiose, D-glucose, gluconate, glycerol, glycogen, maltose, D-mannitol, Dmannose, melezitose, methyl $\alpha$-D-glucopyranoside, methyl $\alpha$-D-mannopyranoside, L-rhamnose, D-ribose, salicin, starch, sucrose, trehalose, turanose and D-xylose, but not from adonitol, D-arabitol, L-arabitol, dulcitol, erythritol, D-fucose, inositol, inulin, 2-ketogluconate, 5-ketogluconate, lactose, D-lyxose, melibiose, methyl $\beta$-D-xylopyranoside, raffinose, sorbitol, L-sorbose, D-tagatose, xylitol or L-xylose. MK-12 is the predominant menaquinone. Major cellular fatty acids are anteiso- $\mathrm{C}_{15: 0}$, anteiso- $\mathrm{C}_{17: 0}$ and iso- $\mathrm{C}_{16: 0}$. Cell-wall sugars are rhamnose, galactose and xylose. Major polar lipids are diphosphatidylglycerol, phosphatidylglycerol, two unknown glycolipids and one unidentified phospholipid. Cell-wall amino acids are 2,4-diaminobutyric acid, glutamic acid, glycine and alanine. The DNA G $+\mathrm{C}$ content of the type strain is $73.4 \mathrm{~mol} \%$.

The type strain, MJ21 $1^{\mathrm{T}}\left(=\mathrm{KCTC} 19549^{\mathrm{T}}=\mathrm{JCM} 16247^{\mathrm{T}}\right)$, was isolated from a farm soil near Daejeon, South Korea.

\section{Acknowledgements}

This work was supported by the Eco-Technopia 21 Project, Ministry of Environment, Republic of Korea (071-081-133).

\section{References}

Buck, J. D. (1982). Nonstaining $(\mathrm{KOH})$ method for determination of gram reactions of marine bacteria. Appl Environ Microbiol 44, 992993.

Cappuccino, J. G. \& Sherman, N. (2002). Microbiology: a Laboratory Manual, 6th edn. San Francisco: Benjamin Cummings.

Collins, C. H. \& Lyne, P. M. (1984). Microbiological Methods, 5th edn. London: Butterworth.

Dorofeeva, L. V., Krausova, V. I., Evtushenko, L. I. \& Tiedje, J. M. (2003). Agromyces albus sp. nov., isolated from a plant (Androsace sp.). Int J Syst Evol Microbiol 53, 1435-1438.

Ezaki, T., Hashimoto, Y. \& Yabuuchi, E. (1989). Fluorometric deoxyribonucleic acid-deoxyribonucleic acid hybridization in microdilution wells as an alternative to membrane filter hybridization in which radioisotopes are used to determine genetic relatedness among bacterial strains. Int J Syst Bacteriol 39, 224-229.

Felsenstein, J. (1985). Confidence limit on phylogenies: an approach using the bootstrap. Evolution 39, 783-791.

Fitch, W. M. (1971). Toward defining the course of evolution: minimum change for a specific tree topology. Syst Zool 20, 406-416.

Gledhill, W. E. \& Casida, L. E., Jr (1969). Predominant catalase negative soil bacteria. III. Agromyces gen. nov., microorganisms intermediary to Actinomyces and Nocardia. Appl Microbiol 18, 340349.

Hall, T. A. (1999). BioEdit: a user-friendly biological sequence alignment editor and analysis program for Windows 95/98/NT. Nucleic Acids Symp Ser 41, 95-98.

Hiraishi, A., Ueda, Y., Ishihara, J. \& Mori, T. (1996). Comparative lipoquinone analysis of influent sewage and activated sludge by highperformance liquid chromatography and photodiode array detection. $J$ Gen Appl Microbiol 42, 457-469.

Hsu, S. C. \& Lockwood, J. L. (1975). Powdered chitin agar as a selective medium for enumeration of actinomycetes in water and soil. Appl Microbiol 29, 422-426.

Jung, S.-Y., Lee, S.-Y., Oh, T.-K. \& Yoon, J.-H. (2007). Agromyces allii sp. nov., isolated from the rhizosphere of Allium victorialis var. platyphyllum. Int J Syst Evol Microbiol 57, 588-593.

Jurado, V., Groth, I., Gonzalez, J. M., Laiz, L. \& Saiz-Jimenez, C. (2005a). Agromyces salentinus sp. nov. and Agromyces neolithicus sp. nov. Int J Syst Evol Microbiol 55, 153-157.

Jurado, V., Groth, I., Gonzalez, J. M., Laiz, L., Schuetze, B. \& SaizJimenez, C. (2005b). Agromyces italicus sp. nov., Agromyces humatus sp. nov. and Agromyces lapidis sp. nov., isolated from Roman catacombs. Int J Syst Evol Microbiol 55, 871-875.

Jurado, V., Groth, I., Gonzalez, J. M., Laiz, L. \& Saiz-Jimenez, C. (2005c). Agromyces subbeticus sp. nov., isolated from a cave in southern Spain. Int J Syst Evol Microbiol 55, 1897-1901.

Kim, M. K., Im, W.-T., Ohta, H., Lee, M. \& Lee, S.-T. (2005). Sphingopyxis granuli sp. nov., a $\beta$-glucosidase-producing bacterium in the family Sphingomonadaceae in $\alpha-4$ subclass of the Proteobacteria. J Microbiol 43, 152-157.

Kimura, M. (1983). The Neutral Theory of Molecular Evolution. Cambridge: Cambridge University Press.

Lee, M., Ten, L. N., Lee, H. W., Oh, H. W., Im, W. T. \& Lee, S.-T. (2008). Sphingopyxis ginsengisoli sp. nov., isolated from soil of a ginseng field in South Korea. Int J Syst Evol Microbiol 58, 2342-2347.

Li, W.-J., Zhang, L.-P., Xu, P., Cui, X.-L., Xu, L.-H., Zhang, Z., Schumann, P., Stackebrandt, E. \& Jiang, C.-L. (2003). Agromyces aurantiacus sp. nov., isolated from a Chinese primeval forest. Int J Syst Evol Microbiol 53, 303-307.

Mesbah, M., Premachandran, U. \& Whitman, W. B. (1989). Precise measurement of the $\mathrm{G}+\mathrm{C}$ content of deoxyribonucleic acid by highperformance liquid chromatography. Int J Syst Bacteriol 39, 159-167.

Minnikin, D. E., O'Donnell, A. G., Goodfellow, M., Alderson, G., Athalye, M., Schaal, A. \& Parlett, J. H. (1984). An integrated procedure for the extraction of bacterial isoprenoid quinones and polar lipids. J Microbiol Methods 2, 233-241.

Moore, D. D. \& Dowhan, D. (1995). Preparation and analysis of DNA. In Current Protocols in Molecular Biology, pp. 2-11. Edited by F. W. Ausubel, R. Brent, R. E. Kingston, D. D. Moore, J. G. Seidman, J. A. Smith \& K. Struhl. New York: Wiley.

Ortiz-Martinez, A., Gonzalez, J. M., Evtushenko, L. I., Jurado, V., Laiz, L., Groth, I. \& Saiz-Jimenez, C. (2004). Reclassification of Agromyces fucosus subsp. hippuratus as Agromyces hippuratus sp. nov., comb. nov. 
and emended description of Agromyces fucosus. Int J Syst Evol Microbiol 54, 1553-1556.

Park, E.-J., Kim, M.-S., Jung, M.-J., Roh, S. W., Chang, H.-W., Shin, K.-S. \& Bae, J.-W. (2010). Agromyces atrinae sp. nov., isolated from fermented seafood. Int J Syst Evol Microbiol 60, 1056-1059.

Rivas, R., Trujillo, M. E., Mateos, P. F., Martínez-Molina, E. \& Velázquez, E. (2004). Agromyces ulmi sp. nov., a xylanolytic bacterium isolated from Ulmus nigra in Spain. Int J Syst Evol Microbiol 54, 1987-1990.

Saitou, N. \& Nei, M. (1987). The neighbor-joining method: a new method for reconstructing phylogenetic trees. Mol Biol Evol 4, 406-425.

Sasser, M. (1990). Identification of bacteria through fatty acid analysis. In Methods in Phytobacteriology, pp. 199-204. Edited by Z. Klement, K. Rudolph \& D. C. Sands. Budapest: Akademiai Kaido.

Schleifer, K. H. (1985). Analysis of the chemical composition and primary structure of murein. Methods Microbiol 18, 123-156.

Schleifer, K. H. \& Kandler, O. (1972). Peptidoglycan types of bacterial cell walls and their taxonomic implications. Bacteriol Rev 36, 407-477.

Stackebrandt, E. \& Goebel, B. M. (1994). Taxonomic note: a place for DNA-DNA reassociation and $16 \mathrm{~S}$ rRNA sequence analysis in the present species definition in bacteriology. Int J Syst Bacteriol 44, 846-849.

Staneck, J. L. \& Roberts, G. D. (1974). Simplified approach to identification of aerobic actinomycetes by thin-layer chromatography. Appl Microbiol 28, 226-231.

Suzuki, K., Sasaki, J., Uramoto, M., Nakase, T. \& Komagata, K. (1996). Agromyces mediolanus sp. nov., nom. rev., comb. nov., a species for "Corynebacterium mediolanum" Mamoli 1939 and for some aniline-assimilating bacteria which contain 2,4-diaminobutyric acid in the cell wall peptidoglycan. Int J Syst Bacteriol 46, 88-93.

Takeuchi, M. \& Hatano, K. (2001). Agromyces luteolus sp. nov., Agromyces rhizospherae sp. nov. and Agromyces bracchium sp. nov., from the mangrove rhizosphere. Int J Syst Evol Microbiol 51, 1529-1537.

Tamura, K., Dudley, J., Nei, M. \& Kumar, S. (2007). MEGA4: molecular evolutionary genetic analysis (MEGA) software version 4.0. Mol Biol Evol 24, 1596-1599.
Ten, L. N., Im, W.-T., Kim, M.-K., Kang, M.-S. \& Lee, S.-T. (2004). Development of a plate technique for screening of polysaccharidedegrading microorganisms by using a mixture of insoluble chromogenic substrates. J Microbiol Methods 56, 375-382.

Thawai, C., Tanasupawat, S., Suwanborirux, K. \& Kudo, T. (2011). Agromyces tropicus sp. nov., isolated from soil. Int J Syst Evol Microbiol 61, 605-609.

Thompson, J. D., Gibson, T. J., Plewniak, F., Jeanmougin, F. \& Higgins, D. G. (1997). The CLUSTAL_X windows interface: flexible strategies for multiple sequence alignment aided by quality analysis tools. Nucleic Acids Res 25, 4876-4882.

Tindall, J. B., Sikorski, J., Simbert, A. R. \& Krieg, R. N. (2007). Phenotypic characterization and the principles of comparative systematics. In Methods for General and Molecular Microbiology, 3rd edn, pp. 330-393. Edited by C. A. Reddy, T. J. Beveridge, J. A. Breznak, G. A. Marzluf, T. M. Schmidt \& L. R. Snyder. Washington, DC: American Society for Microbiology.

Wayne, L. G., Brenner, D. J., Colwell, R. R., Grimont, P. A. D., Kandler, O., Krichevsky, M. I., Moore, L. H., Moore, W. E. C., Murray, R. G. E. \& other authors (1987). International Committee on Systematic Bacteriology. Report of the ad hoc committee on reconciliation of approaches to bacterial systematics. Int J Syst Bacteriol 37, 463-464.

Yoon, J.-H., Schumann, P., Kang, S.-J., Park, S. \& Oh, T.-K. (2008). Agromyces terreus sp. nov., isolated from soil. Int J Syst Evol Microbiol 58, 1308-1312.

Zgurskaya, H. I., Evtushenko, L. I., Akimov, V. N., Voyevoda, H. V., Dobrovolskaya, T. G., Lysak, L. V. \& Kalakoutskii, L. V. (1992). Emended description of the genus Agromyces and description of Agromyces cerinus subsp. cerinus sp. nov., subsp. nov., Agromyces cerinus subsp. nitratus sp. nov., subsp. nov., Agromyces fucosus subsp. fucosus sp. nov., subsp. nov., and Agromyces fucosus subsp. hippuratus sp. nov., subsp. nov. Int J Syst Bacteriol 42, 635-641.

Zhang, D.-C., Schumann, P., Liu, H.-C., Xin, Y.-H., Zhou, Y.-G., Schinner, F. \& Margesin, R. (2010). Agromyces bauzanensis sp. nov., isolated from soil. Int J Syst Evol Microbiol 60, 2341-2345. 